\title{
A proposal for a federalized unemployment insurance mechanism for Europe
}

\author{
Leila E. Davis* \\ Department of Economics, Middlebury College, VT, USA \\ Charalampos Konstantinidis** \\ Department of Economics, University of Massachusetts Boston, MA, USA \\ Yorghos Tripodis*** \\ Department of Biostatistics, School of Public Health, Boston University, MA, USA
}

\begin{abstract}
The ongoing crisis in the eurozone, together with growing evidence of structural imbalances, points to a role for new institutions to support a more stable European Monetary Union (EMU) structure. As is well established in the context of monetary union when business cycles are not synchronized, a system of fiscal transfers can support monetary union. Unemployment insurance (UI) is, in particular, a key component of fiscal crisis management. UI supports household incomes during downturns, and also acts as an automatic stabilizer, thereby helping individual countries respond to asymmetric shocks. This paper proposes a 'federalized' EMU-level UI mechanism as one program that can contribute to a system of fiscal transfers in the EMU, and estimates the cost of the proposed system under different financing and eligibility scenarios. We find that, under a variety of reasonable institutional parameters, such a system is fiscally feasible with limited reason to expect adverse employment effects in member countries. We conclude that fiscal transfers extended via automatic stabilizers are a productive avenue towards a more stable eurozone architecture.
\end{abstract}

Keywords: eurozone, unemployment insurance, fiscal transfers

JEL codes: $E 45, E 61, E 62$

\section{INTRODUCTION}

This paper estimates the cost of a European Monetary Union (EMU)-wide unemployment insurance (UI) system, and argues that such a system is both fiscally feasible and has the potential to contribute to a more stable EMU architecture. The ongoing crisis in Europe has raised questions about structural imbalances in the eurozone and the sustainability of the EMU's current structure (De Grauwe 2006; Dullien/Fritsche 2009; Nikiforos et al. 2015). This literature points to renewed interest in the conditions for

* Corresponding author: Department of Economics, Middlebury College, Middlebury, VT, 05753; email: ldavis@middlebury.edu.

** Department of Economics, University of Massachusetts Boston, Boston, MA 02125; email: konstantinidis@umb.edu.

*** Department of Biostatistics, School of Public Health, Boston University, Boston, MA 02118; email: yorghos@bu.edu.

Received 27 October 2015, accepted 22 July 2016 
successful monetary union, and to a need for concrete discussions about specific institutions and policies that can contribute to a more stable EMU (De Grauwe 2012; 2013; Hein/Detzer 2014).

One direction for reform is a set of fiscal transfers to cushion adverse asymmetric shocks to EMU countries (Dullien/Schwarzer 2009). Theoretical support for fiscal transfers in the European context is found in optimum currency area theory (Mundell 1961; Kenen 1969; Krugman 2012), and also more recently in the context of surplus-recycling mechanisms targeting systematic trade imbalances across eurozone countries (Varoufakis 2011). As the eurozone debt crisis has deepened, policy calls for across-EMU fiscal transfers have also grown. The IMF's July 2015 policy report on Greece, for example, explicitly recommends direct fiscal transfers to the Greek budget to help quell the debt crisis (IMF 2015: 3). Similarly, Obstfeld (2013) argues that eurozone countries cannot maintain both cross-border financial integration and financial stability simultaneously with national fiscal independence.

The logic for fiscal transfers is well established: member states in monetary unions have neither independent monetary authority nor exchange-rate control and, therefore, have limited policy options with which to respond to adverse shocks. Fiscal transfers across member countries can, however, mitigate the impact of asymmetric shocks, particularly given restrictions on domestic fiscal spending. Accordingly, fiscal transfers may be particularly important in the European context for at least two additional reasons. First, the budgetary restrictions of the Stability and Growth Pact constrain the use of counter-cyclical fiscal policy by individual member states as a response to adverse shocks. Second, significant intra-European trade suggests that fiscal transfers that maintain demand in the European periphery - an important source of external demand for the core - also support aggregate demand in the core (Baldwin 2006).

In this paper, we contribute to the discussion on fiscal transfers in the EMU via a detailed investigation of one specific policy proposal: an EMU-wide UI system, which we find to be one fiscally feasible mechanism with the potential to generate short-term stabilizing transfers across EMU countries. Unemployment insurance is a key component of fiscal crisis management: during downturns, UI supports both household incomes and aggregate demand. Furthermore, because unemployment insurance is a direct injection of fiscal spending to households with relatively high propensities to consume, UI is expected to be associated with higher-than-average fiscal spending multipliers. Finally, the fact that business cycles in the EMU remain, at best, imperfectly synchronized, implies that transferring automatic stabilizers like UI to the 'federal' level amplifies the macroeconomic efficacy of fiscal transfers by directing spending towards member countries currently furthest from their business-cycle peak. Along these lines, a growing literature emphasizes the point-in-business cycle dependence of fiscal multipliers (Auerbach/Gorodnichenko 2012; Fazzari et al. 2015), as well as cross-country spillovers from fiscal policy (Auerbach/Gorodnichenko 2013).

The idea for a European-wide UI program has a long history in both academic and policy circles. In 1975, the Marjolin report stated that a European community unemployment benefit fund would have 'beneficial effects on the economy and society as a whole' (Commission of the European Communities 1975: 34). In June 2014, EU Employment Commissioner Laszlor Andor urged the eurozone to set up a common UI program as part of a social and economic safety net (Andor 2014). An empirical literature, furthermore, suggests that an EMU-wide UI program may mitigate output fluctuations (Dullien 2007; 2012; 2013; Dullien/Fichtner 2013; Dolls et al. 2014), and support household incomes (Jara/Sutherland 2014). Dullien (2013), in particular, analyses the stabilization potential of the system for recessionary periods in EMU countries, and finds evidence 
of a sizable potential stabilization impact for a number of cases in which there have been serious downturns. ${ }^{1}$

In this paper, we build on the literature on EMU-wide UI in three ways. First, we lay out a detailed institutional proposal, and analyse the cost and fiscal feasibility of the system under a range of financing and eligibility scenarios. These calculations and sensitivity analysis build on and contribute to the existing literature, by clarifying fiscal trade-offs between policy parameters in designing such a system. Second, we use IMF projections to extend the analysis through 2020. Projections are particularly important in the post2008 context because the estimated annual flow into the fund has been negative since the onset of the 2008 crisis. These projections point, however, to recovery in the accumulated stock of the fund in coming years, thereby providing important support for the feasibility of the institutional design and policy parameters explored in this paper.

For all years of the EMU, and including projections through 2020, we find that an EMU-wide UI fund is fiscally feasible for a range of institutional scenarios. Specifically, we define a scenario to be fiscally feasible if the accumulated stock of the fund is positive in all years for parameters sufficiently in line with current domestic labor market institutions to mitigate adverse employment effects (from either labor demand responses to higher payroll taxes, or labor supply responses to benefit levels exceeding the domestic minimum wage). Importantly, this definition implies that the scheme proposed in this paper does not require large-scale convergence in labor market institutions prior to implementation. In particular, the payroll tax necessary to finance the scheme does not exceed 1.5 percent, which is less than or equal to existing payroll taxes in most EMU countries and which, in the institutional design in this paper, would be 'earmarked' for an EMUlevel fund.

Third, we assess two consequences of the proposed system closely tied to political feasibility: distributional outcomes across EMU countries and output stabilization effects. We find that distributional consequences across member states are limited over time, but more importantly, net contributions to the scheme vary with a country's business cycle, such that countries are on average net contributors to (beneficiaries of) the fund during expansions (recessions). This feature of the system stems from the proposed design, which links each country's contributions and benefits to its wage base, as well as from the fact that UI is an automatic stabilizer. Finally, calculations point to a positive output stabilization effect, suggesting that 'federalized' UI guaranteed at the eurozone level is one fiscal mechanism that can contribute to a more stable European architecture. By using business-cycle-dependent multipliers, as opposed to time- and place-invariant multipliers, these calculations extend previous analyses of stabilization in an important respect. In particular, state-dependent multipliers are key to exploring the stabilization dimensions of federalized fiscal mechanisms - and, in particular, fiscal mechanisms tied to automatic stabilizers - given asymmetric shocks and asynchronous business cycles in the eurozone.

Finally, it is important to recognize that, because UI spending constitutes a small percentage of European GDP, the independent stabilization potential of 'federalizing' UI is limited (Claeys et al. 2014). The analysis in this paper highlights, however, the stabilization potential of UI as one part of a broader system of federalized fiscal mechanisms for Europe. Furthermore, the analysis in this paper points to a particular role for fiscal transfers extended via automatic stabilizers as a productive avenue towards a more stable European architecture.

1. See Claeys et al. (2014) and Beblavý et al. (2015) for comprehensive surveys of the debate on the benefits and drawbacks of eurozone-level UI that integrate the policy-oriented and the academic literature on the topic. 
The paper is organized as follows. Section 2 discusses UI in the EMU context; Section 3 introduces institutional specifics and plausible parameter ranges for the proposed system; Section 4 presents cost calculations for the proposed institutional design; Section 5 discusses distributional impacts and stabilization properties; and Section 6 briefly concludes.

\section{UNEMPLOYMENT INSURANCE AND THE EUROPEAN MONETARY UNION}

The post-2008 period in the EMU highlights the role of unemployment insurance in the fiscal response to crisis. During recessions UI plays a key microeconomic role by supporting household incomes and contributing to an economic safety net. At the macroeconomic level, UI acts as an automatic stabilizer supporting aggregate demand. First, in line with empirical evidence pointing to the particular efficacy of 'targeted transfers' in the fiscal response to crisis (Oh/Reis 2012), the fact that UI directly supports consumption among households with recent declines in income and thus above-average propensities to consume suggests that UI is a particularly effective form of fiscal spending (that is, it entails an above-average multiplier).

Second, the expansionary effect of fiscal policy is stronger in recessions - when there is considerable 'slack' in the economy - than during expansions, or as the economy approaches full employment (Auerbach/Gorodnichenko 2012; Fazzari et al. 2015). Lack of business-cycle synchronization across EMU economies, therefore, provides an additional rationale for fiscal transfers in the eurozone. ${ }^{2}$ Fiscal transfers in the form of automatic stabilizers direct fiscal spending towards member states currently furthest from full employment, with larger multipliers. Simultaneously, of course, automatic stabilizers help prevent overheating in member countries at or above full employment by automatically reducing spending in these economies. Finally, the automatic nature of UI spending is particularly advantageous in the European case given the small scale of the discretionary EU-level budget, which suggests that important features of fiscal transfers in the EMU include automatic funding and dispersion of funds.

As an automatic stabilizer, UI spending increases during recessions. Consider the post2008 period in the EMU: crisis countries' UI spending increases substantially after 2008, despite a concurrent push to restrict total government expenditures. Table 1 summarizes the change in UI spending as a share of total government spending between 2008 and 2012 in the five countries central to the post-2008 crisis in Europe. In Greece, for example, UI spending increases approximately 50 percent, from 0.84 percent to 1.23 percent of total government spending from 2008 to 2012 . Ireland - frequently cited as an example of 'successful austerity' - records even larger growth in UI: as a percentage of government expenditures, UI increased 89.9 percent between 2008 and 2012, from 2.86 percent to 5.43 percent of total spending. Over the same time period total government spending contracted 12.01 percent in Greece and 9.42 percent in Ireland. While total government spending grew between 2008 and 2012 in Portugal, Italy, and Spain, the percentage growth in total government expenditures is dwarfed by the percentage growth in UI spending. Thus, these data suggest that UI constitutes a largely un-relievable portion of

2. Altavilla (2004) finds differences in the timing of EMU members' business cycles at the inception of the euro, and more recent evidence suggests that business cycle convergence among eurozone countries during the 1990s ended roughly with the introduction of the euro (Crespo-Cuaresma/ Fernandez-Amador 2013). 
Table 1 Percentage change in unemployment expenditures and government spending in the EMU crisis economies, 2008 and 2012

\begin{tabular}{lccccccc}
\hline & \multicolumn{3}{c}{$\begin{array}{c}\text { Unemployment benefits as a } \\
\text { percentage of government } \\
\text { expenditure }\end{array}$} & $\begin{array}{l}\text { Pctg change in } \\
\text { UI expenditure } \\
(2008-2012)\end{array}$ & $\begin{array}{l}\text { Pctg change in } \\
\text { gov't expenditure } \\
(2008-2012)\end{array}$ \\
\cline { 2 - 5 } & 2008 & 2009 & 2010 & 2011 & 2012 & & -9.42 \\
Ireland & 2.86 & 4.83 & 3.95 & 5.10 & 5.43 & 72.03 & 3.53 \\
Italy & 0.73 & 0.99 & 1.06 & 1.08 & 1.25 & 78.48 & -12.01 \\
Greece & 0.84 & 1.14 & 1.32 & 1.51 & 1.23 & 29.05 & 1.54 \\
Portugal & 1.94 & 2.32 & 2.37 & 2.35 & 3.17 & 66.05 & 9.12 \\
Spain & 3.02 & 5.00 & 4.76 & 5.19 & 4.91 & 77.55 & \\
\hline
\end{tabular}

Notes: Detailed data on the composition of government expenditure is only available through 2012. We do not expect the approximation wherein the sum of the final two columns (growth in UI spending, and growth in government expenditure) equals the third column (growth in UI/G) to hold in the cases for which there is significant movement in the denominator (change in government spending).

Source: Eurostat. Unemployment benefits are defined as benefits compensating for loss of earnings where a person is capable and available for work, but unable to find suitable employment; government spending is defined as total annual government expenditure.

government expenditure during downturns. ${ }^{3}$ Nonetheless, the net fiscal stimulus of transferring UI to the European level for a country's domestic budget is not likely to be substantial on average, given that an EMU-wide UI system transfers both revenue collection and benefit disbursement to the EMU-level fund. However, the stimulus effect on a country's GDP depends on the size of the multiplier and, consequently, an individual country's point in the business cycle (discussed further in Section 5.2).

Two additional points are relevant to note. First, these figures do not include long-term unemployed for whom benefits have expired. Given the length and depth of this particular crisis the duration of unemployment is an important factor to keep in mind. However, this paper emphasizes short-term unemployment, discussed further in Section 3. Second, UI is a relatively minor component of government spending, particularly in Italy and Greece, suggesting that - especially when considering small economies like Greece - transferring UI to the eurozone level is a relatively inexpensive policy. If limited fiscal costs are also associated with stabilization of the currency zone, there is a strong rationale to further investigate the plausibility of the policy.

\section{AN EMU-WIDE UI SCHEME: INSTITUTIONAL DESIGN}

In this section we outline a simple institutional structure for an EMU-wide UI scheme, which allows us to clarify policy parameters under which such a system is fiscally feasible, and isolate specific fiscal trade-offs in the design of such a scheme. This structure forms the basis for the cost calculations presented in Section 4.

3. In the European context, however, it is important to recognize that pressure on individual countries' budgets during (severe) downturns - given the Stability and Growth Pact - may lead to pro-cyclical cuts in automatic stabilizers (like UI) at the individual country level (Claeys et al. 2014: 2). 
The basic objective in the design of the scheme is to consider the fiscal plausibility of short-term unemployment assistance guaranteed at the EMU level. Individual countries are allowed to 'top up' and provide additional benefits - either higher levels or longer duration - beyond those guaranteed by the EMU if they choose, but our analysis is concentrated on the implications of the EMU-wide UI scheme. To estimate the net cost of the system (the yearly surplus or deficit), we calculate contributions paid into the system (revenues) and total benefits paid out of the system in each year (payouts). The calculations use ex-ante figures and, therefore, do not account for impacts of the proposed policy over time. Note, however, that - because the impact of the demand injection from UI in any given year does not enter the next period's figures - ex-ante numbers bias against fiscal feasibility. Because the system utilizes existing administrative structures for collecting revenues and dispensing benefits, we assume it does not entail significant costs in terms of new administrative infrastructure. Thus, the size of the fund is the annual difference between contributions and benefit payouts - that is, the sum of the yearly surplus or deficit across countries - aggregated over time. ${ }^{4}$ We can, therefore, express the stock of the fund and the yearly flows of revenues and benefit payouts as:

$$
\begin{gathered}
\text { Fund }=\sum_{t}\left(\text { Revenues }_{t}-\text { Payouts }_{t}\right) \\
\text { Revenues }_{t}=\sum_{i} \tau * W_{i, t} \\
\text { Payout }_{t}=\sum_{i}\left(e_{i, t} U_{i, t}\right) B_{i, t},
\end{gathered}
$$

where the subscripts $i$ and $t$ refer to country and year, $W_{i, t}$ is the taxable wage base, $\tau$ is the funding tax, $e_{i, t}$ is the percentage of unemployed eligible for benefits, $U_{i, t}$ is the total number of unemployed, and $B_{i, t}$ is the benefit level. Equations (1)-(3) indicate that the key elements of a UI scheme to estimate fiscal cost are, first, the method of funding; second, the eligibility criteria; and, third, the level and duration of benefits. The variables describing this baseline design, including the baseline parameter assumptions introduced in Sections 3.1 and 3.2 below, are summarized in Table 2.

\subsection{Funding}

Following most existing UI systems in the EMU, contributions are defined by a payroll $\operatorname{tax} \tau^{p}$ levied on each country's taxable wage base:

$$
\text { Revenues }_{t}=\sum_{i} \tau^{p} W_{i, t} \text {. }
$$

Taking the payroll tax to be constant over time and place, we consider a baseline tax of 1.5 percent. Note that this payroll tax is not an additional EMU-level tax on top of existing national payroll taxes; instead, this payroll tax 'earmarks' the first 1.5 percent of domestic payroll taxes for the EMU-level fund. Importantly, this baseline tax is less than or equivalent to existing payroll taxes in most EMU economies and, importantly,

4. Thus, this institutional design stabilizes over space (that is, across eurozone countries at any given point in time), and time (that is, by running a surplus during expansions and depleting reserves during contractions) (Dullien 2012). 
Table 2 Summary of baseline policy design

\begin{tabular}{|c|c|c|}
\hline Variable & Symbol & Baseline value \\
\hline \multicolumn{3}{|l|}{ Revenues (contributions): } \\
\hline Taxable wage base & $W_{i, t}$ & $\begin{array}{l}83 \% \text { of gross wages (gross wages vary } \\
\text { by country and year) }\end{array}$ \\
\hline \multicolumn{3}{|l|}{ Benefit pay-outs: } \\
\hline Total unemployed & $U_{i, t}$ & \\
\hline $\begin{array}{l}\text { Share of unemployed that } \\
\text { are eligible }\end{array}$ & $e_{i, t}$ & \\
\hline Eligible unemployed & $e_{i, t} U_{i, t}=U_{i, t}^{S T}$ & Short-term unemployed \\
\hline Minimum wage & $w_{i, t}^{\min }$ & \\
\hline Pct wage replacement & $\beta^{, \imath}$ & $45 \%$ \\
\hline
\end{tabular}

Notes: Subscripts $i$ and $t$ denote country and year, respectively. Variables without subscripts are nonvarying parameters.

in the large EMU economies. ${ }^{5}$ Thus, the system transfers fiscal authority from the country level to the EMU level, largely without cost implications for firms or budgetary implications for governments. The fact that we are not imposing an additional 1.5 percent payroll tax is an important feature of the scheme, given the baseline institutional design imposes a scheme largely in line with the current tax environment in EMU countries, thereby avoiding contentions regarding adverse employment effects.

Note, also, that we do not specify who pays the tax (firms, employees, federal or local government), such that existing national pay-in systems simply pay into the EMU-level fund. In Germany, for example, firms, workers and the state each contribute 1.5 percent of payroll (such that total payroll contributions are 4.5 percent); as such, the existing funding system in Germany is sufficient to contribute to the EMU fund while also providing additional for example, long-term - benefits domestically. ${ }^{6}$ Importantly, by transferring existing national systems to the EMU level, we neither require convergence in the structure of existing UI systems across the EMU, nor do we enter into a debate about 'optimal' UI design.

The payroll tax is levied on the taxable wage base, which we define as a constant percentage across time and place of each country's annual wage base. A taxable wage base less than 100 percent reflects that payroll taxes generally do not apply to an individual's wages above a certain threshold. The definition of the taxable wage base is clearly a policy choice; however, because our objective in the baseline cost calculations is to maintain taxes in line with existing systems, we assume a taxable wage base of 83 percent to reflect the current institutional setting. Because EMU data is collected nationally rather than at the monetary union level, this assumption is based on US data, where wages subject to payroll tax have averaged 83 percent since 1950 . This post-1980 average, furthermore, masks a decline in the taxable wage base from a maximum of 90 percent in 1983 to 83 percent in 2012 (SSA 2013); rising inequality due to income growth at the top of the US distribution implies that a greater share of total earned wages exceeds the payroll tax cap.

5. Four EMU member countries currently have payroll taxes less than 1.5 percent: Luxembourg (0 percent), Estonia (1 percent), Slovakia (1 percent), and Slovenia (0.06 percent) (SSA 2014).

6. Any additional benefits beyond those guaranteed by the EMU-level fund and financed by the 1.5 percent payroll tax directed to the EMU-level fund, would be financed and administered by an additional payroll tax at the domestic level. 
Because the top-end inequality that decreases the share of the aggregate wage base subject to payroll taxes is lower in Europe than in the US (Alvaredo et al. 2014), the higher end of the US range is expected to be more applicable to the European case. Thus, 83 percent is considered a lower bound for the EMU, biasing the baseline towards fiscal infeasibility; consequently, we also show sensitivity calculations in Section 4 analysing values for the taxable wage base ranging from 80 percent to 90 percent.

\subsection{Eligibility and benefits}

With regard to eligibility, the primary objective is to capture short-term unemployment, such that the proposed scheme generates short-term fiscal transfers in response to asymmetric cyclical shocks, rather than permanent redistributive transfers between member states. Accordingly, eligibility can be defined in various ways. Dullien (2007: 36), for example, proposes eligibility defined by 12 months of consecutive employment in the last 24 months, with a 12-month benefit cap based on prior job tenure. Because the individual-level panel required for this calculation is unavailable, however, Dullien assumes 50 percent of the short-term unemployed are eligible. The primary objective of this assumption is to provide 12 full months of benefits and include individuals who become unemployed twice in a short period, while excluding both the seasonally unemployed and, more broadly, individuals who are ineligible for unemployment benefits due to insufficient recent employment. ${ }^{7}$ Notably, this assumption aims, in part, to address a common contention that a significant share of short-term unemployment in the EMU is seasonal and, accordingly, reflects structural characteristics of particular European economies, including differences between core and periphery.

Using quarterly data to capture seasonal unemployment, we estimate the median share of seasonal unemployment in short-term unemployment across EMU economies to be 7.6 percent. $^{8}$ Seasonal unemployment does not exceed 28.0 percent of short-term unemployment for any country in any year from 1999 to the present. Furthermore, seasonal unemployment does not follow a clear core-periphery pattern: Finland, Estonia, Cyprus, and Italy have the highest median shares of seasonal unemployment, whereas Malta, Ireland, and Spain have the lowest. Thus, given the available data, and because seasonal unemployment constitutes a relatively small share of short-term unemployment, restricting eligibility to 50 percent of the short-term unemployed - in part on the basis of seasonality - may bias calculations towards fiscal feasibility, by reducing benefits paid out and thus increasing the accumulated stock in the fund.

Our baseline eligibility scenario, therefore, guarantees EMU-level benefits to 100 percent of the short-term unemployed, where short-term unemployment is defined as unemployment spells lasting less than 12 months. Dolls et al. (2014) utilize the same criterion. This eligibility requirement can be interpreted as an upper bound for the fiscal cost of the system, given that stricter eligibility assumptions bias the system towards fiscal infeasibility. For comparability, calculations based on stricter eligibility requirements are also included in Section 4.

7. Dullien (2013) notes that data availability restricts the possibility of exactly computing the share of short-term unemployed in each country that is eligible for benefits on the basis of recent work history.

8. Using Eurostat data, we extract the seasonal component of unemployment by subtracting the quarterly seasonally adjusted unemployment rate from the non-seasonally adjusted data. We then calculate the ratio of the seasonal component of unemployment relative to short-run unemployment. 
Finally, we define benefit levels as a percentage of the country-specific minimum wage and, in the baseline calculations, replace 45 percent of minimum wages to the eligible unemployed. ${ }^{9}$ As opposed to a lump-sum payment, benefits tied to the minimum wage link each country's benefit level to its wage level, thereby guaranteeing benefits sufficient to support aggregate demand in higher-income economies without defining benefits that exceed any country's minimum wage. Note that the lowest existing benefit levels - defined by the UI systems of smaller EMU economies (for example, Malta, Slovakia, Estonia) are too low to support incomes or stabilize output in larger EMU economies. The definition of benefits used here, therefore, balances the goals of supporting household incomes and aggregate demand against possible dis-employment effects deriving from a labor supply response to benefits exceeding the minimum wage. Linking each country's benefits and contributions, furthermore, increases the political feasibility of implementation in higher-income EMU countries.

Thus, total yearly benefits paid out of the system are defined as:

$$
\text { Payouts }_{t}=\sum_{i}\left(e_{i, t} U_{i, t}\right) B_{i, t}=\left(U_{i, t}^{S T}\right) * \beta w_{i, t}^{\text {min }},
$$

where $\beta$ is 45 percent in the baseline scenario, and $U^{S T}$ denotes the number of short-term unemployed. In addition to the baseline, sensitivity calculations in Section 4 analyse combinations of the payroll tax and taxable wage base necessary to replace up to 50 percent of minimum wages. ${ }^{10}$

\section{THE FISCAL COST OF EMU-WIDE UNEMPLOYMENT INSURANCE}

\subsection{The baseline proposal}

Figure 1 presents cost calculations for the baseline scheme outlined above, based on a 1.5 percent payroll tax, 83 percent taxable wage base, and benefits replacing 45 percent of the minimum wage for (100 percent of) the short-term unemployed. This figure plots four series: contributions to the scheme (revenues); benefits paid out; the yearly surplus or deficit, calculated as the difference between contributions and benefits; and the accumulated stock of the fund calculated using a 2 percent discount rate. ${ }^{11}$ The series

9. Five EMU countries (Austria, Cyprus, Finland, Germany, and Italy) do not have a minimum wage for the relevant period, although Germany instituted one in 2015 that we utilize for the projections. On average across EMU countries, the minimum wage is approximately 50 percent of the average wage. For these five countries we therefore construct a shadow minimum wage, utilizing the average relationship in each year between average wages and minimum wages in other EMU countries. Note that median wage data are unavailable. Use of mean, rather than median, wages biases the cost calculations towards fiscal infeasibility, given that mean wages - and, thus, benefit levels based on mean wages - are skewed upward in unequal economies.

10. Estonia, Latvia, and Slovakia (plus Slovenia, under certain circumstances) currently pay 50 percent of earnings.

11. The size of the fund shown in Figure 1 and the final column of Table 3 is calculated with a 2 percent discount rate. Note, however, that we have not assigned a return to the accumulated funds in the system, despite the fact that these funds may be invested to earn, for example, a risk-free rate of return. To account for returns earned on the accumulated funds in the system, we can instead calculate the stock of the fund with a 0 percent discount rate, assuming that the risk-free rate of return is approximately equal to the discount rate. For comparability, calculations with a 0 percent discount rate are shown in Table 3, column 4. 


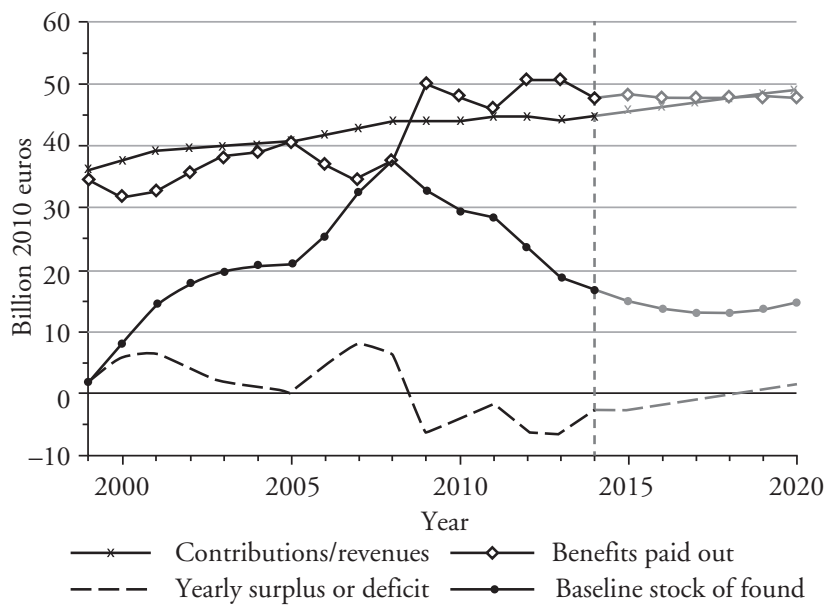

Notes: The baseline calculations are based on a 1.5 percent payroll tax, 83 percent taxable wage base, and 45 percent minimum replacement to 100 percent of the short-term unemployed. All calculations are in constant 2010 euros, based on the GDP deflator. Yearly contributions/revenues are the product of the payroll tax, taxable wage base, and gross wages. Benefits paid out utilize the minimum wage and (number of) short-term unemployed. The yearly surplus/deficit is defined as contributions less benefits paid out. The stock of the fund is the aggregation of the yearly surplus/ deficit over time, calculated with a 2 percent discount rate.

Sources: AMECO; Eurostat; and the IMF's World Economic Outlook. See the Appendix for details.

Figure 1 Baseline scenario, billion 2010 euros

are also shown in Table 3. The calculations are based on gross wage, unemployment, and inflation data from AMECO, and minimum wage and employment duration statistics from Eurostat for 1999-2014; these data are extended through 2020 with projections from AMECO and the IMF's World Economic Outlook. ${ }^{12}$

Figure 1 highlights that, with the baseline parameters, the accumulated stock of the fund - shown by the solid black line - is positive in all years. Thus, the baseline calculations point to the fiscal feasibility of an EMU-wide UI scheme: the fund is expected to run a sustained surplus, given parameters that are not expected to generate adverse employment effects. Figure 1, furthermore, highlights that despite running a deficit between 2009 and 2014, the fund is projected to be in surplus beginning in 2018, thereby reversing the reduction in the accumulated stock of the fund following the 2008 global financial crisis.

As the fund exceeds zero for all years, the baseline scenario also suggests that the system may be feasible when funded by lower taxes, or when financing higher benefits. Recall, furthermore, that the baseline parameter assumptions regarding both the taxable wage base (83 percent) and eligibility (100 percent of the short-term unemployed) bias the fund towards fiscal infeasibility. Increases in the taxable wage base and more restrictive eligibility requirements would both further increase this fiscal surplus.

12. The data set is described in the Appendix. 
102 European Journal of Economics and Economic Policies: Intervention, Vol. 14 No. 1

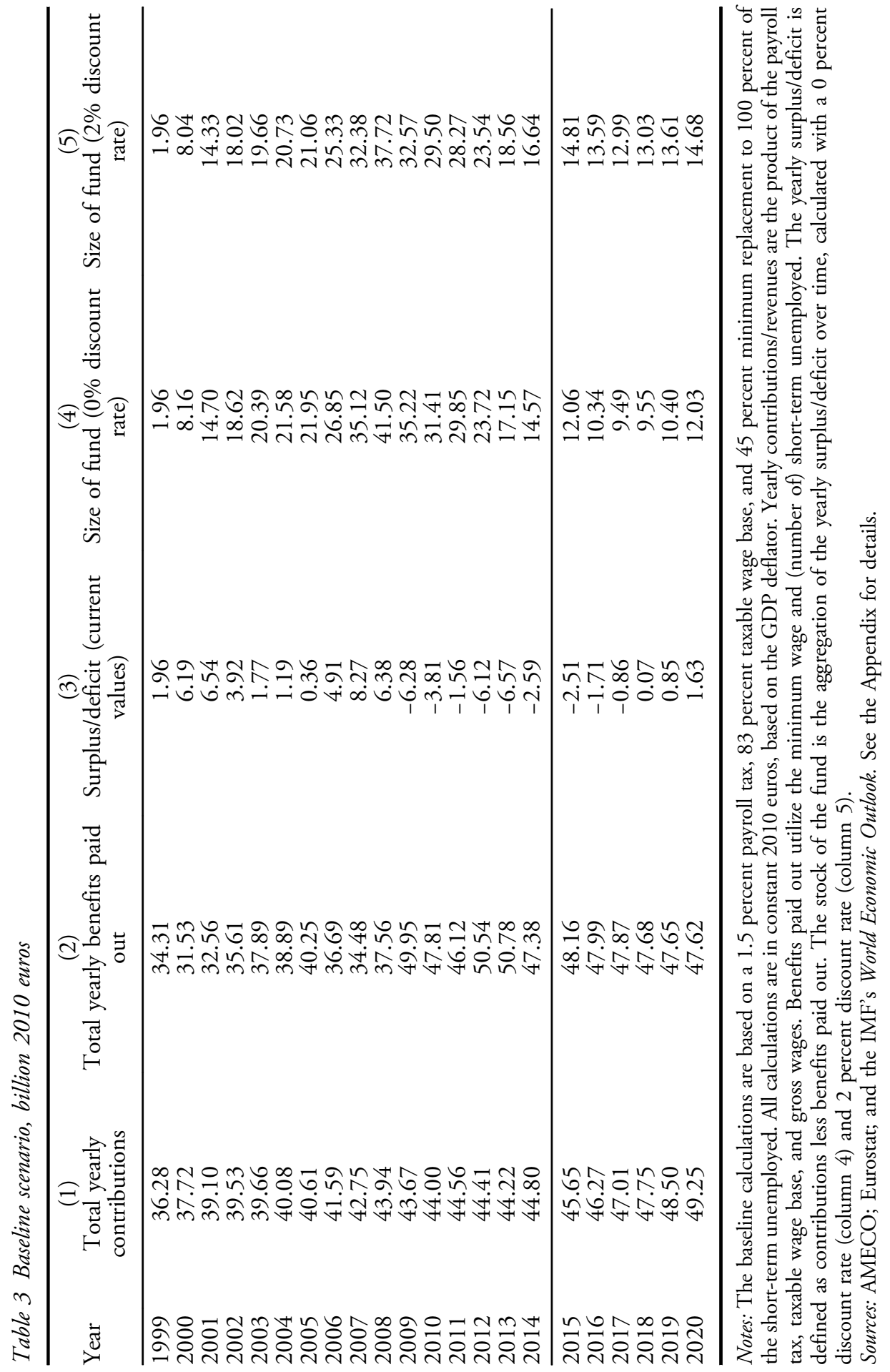




\subsection{Sensitivity calculations}

In this section, we analyse the fund's sensitivity to plausible ranges of the payroll tax and taxable wage base, as well as to variations in eligibility requirements. In each case, we also establish the parameters necessary to finance benefits replacing 50 percent of the minimum wage. Subsequently, Section 4.3 considers benefit expansions taking the form of extended-period benefits in cases of deep crises, rather than higher minimum wage replacement. These sensitivity calculations indicate that, although the fund's fiscal feasibility is sensitive to specific parameter values, the system is feasible for reasonable ranges of the key parameters and, importantly, for taxes sufficiently in line with current tax rates to mitigate the possibility of dis-employment effects.

To begin, Figure 2 plots the baseline stock of the fund, as well as the evolution of the fund over time for variations in the benefit level ranging from 40 to 50 percent replacement of the minimum wage. Figure 2 indicates that, when holding all other parameters equal to the baseline, 45 percent minimum wage replacement (that is, the baseline) is the maximum benefit that can be financed while maintaining a positive fund for all years. While 45 percent minimum wage replacement is feasible, 46 percent minimum wage replacement causes the fund to fall below zero in the projections (2016-2020). ${ }^{13}$ Thus,

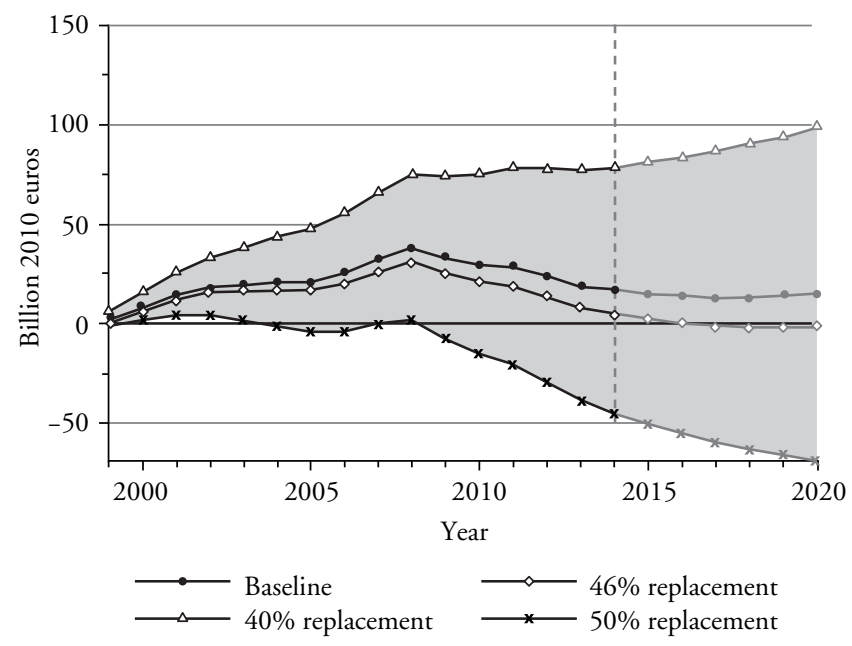

Notes: The calculations are based on a 1.5 percent payroll tax, 83 percent taxable wage base, and eligibility to 100 percent of the short-term unemployed. The figure highlights a range of benefit levels, based on minimum wage replacement ranging from 40 to 50 percent of the yearly, national minimum wage. All calculations are in constant 2010 euros, based on the GDP deflator. Calculations utilize a 2 percent discount rate.

Sources: AMECO; Eurostat; and the IMF's World Economic Outlook. See the Appendix for details.

Figure 2 Baseline, with variations in the benefit level: stock of fund (1999-2020)

13. The projected deficit with 46 percent minimum wage replacement is, however, quite small particularly in 2016-2017 (0.34 billion in 2016 and 1.69 billion in 2017) - and is sensitive to assumptions used in the projections regarding the reincorporation of short- versus long-term unemployed into the labor force during recoveries, which are explained in the Appendix. 
relative to the baseline scenario, a higher payroll tax, higher taxable wage base, or stricter eligibility requirements would be necessary to finance higher benefits.

Turning to the funding parameters, Figures 3 and 4 plot the accumulated stock of the UI fund for payroll taxes ranging from 1.4 percent to 1.6 percent, and for taxable wage base values between 80 percent and 90 percent, respectively. In each case, the baseline is shown for comparability by the solid line. First, Figure 3 highlights that, when holding all other parameters equal to the baseline, the scheme is fiscally feasible for payroll taxes greater than or equal to 1.48 percent, denoted by the line marked by white diamonds plotted directly below the baseline. Second, Figure 4 highlights that, with all other parameters equal to the baseline, the scheme is fiscally feasible for values of the taxable wage base greater than or equal to 82 percent, again marked by white diamonds and plotted directly below the baseline fund. Recall, however, that the baseline parameter selection for the taxable wage base is likely underestimated, and that the taxable wage base in Europe is expected to be closer to the top end of the range plotted in Figure 4. Accordingly, Figure 4 also highlights that a higher taxable wage base dramatically increases the fund's accumulated surplus. Relatively small increases in the payroll tax, similarly, substantially increase the accumulated stock in the system over time.

One way to analyse the size of the surplus accumulated in the system is to establish combinations of payroll tax and taxable wage base necessary to replace 50 percent of the minimum wage for the short-term unemployed. First, holding the taxable wage base constant at 83 percent, a payroll tax of 1.7 percent is necessary to cover 50 percent of each country's minimum wage. Given the sensitivity of the fund to the taxable wage base, however, 1.7 percent is a clear upper bound estimate for the payroll tax required

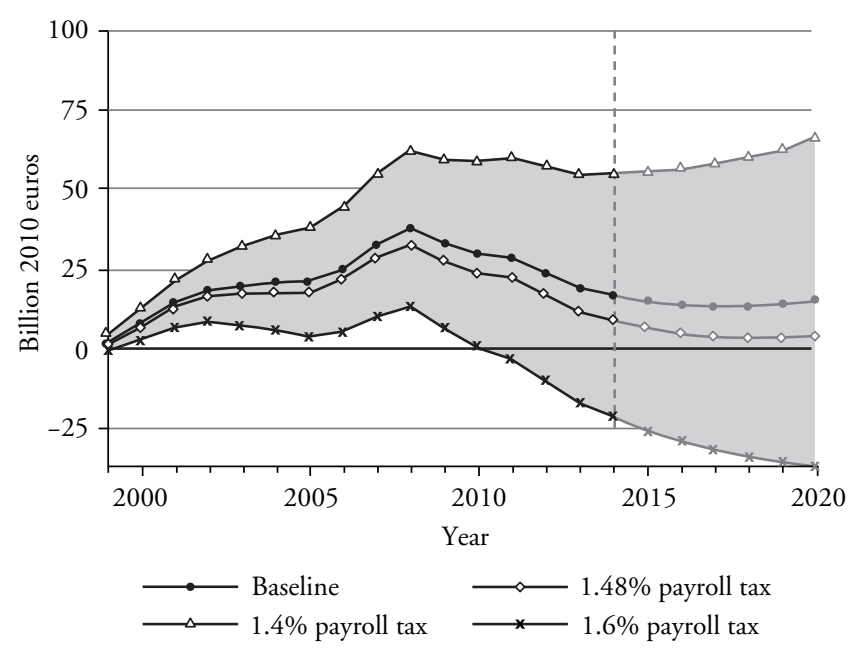

Notes: The calculations are based on an 83 percent taxable wage base, eligibility to 100 percent of the short-term unemployed, and benefits equal to 45 percent minimum wage replacement. The figure presents the stock of the fund over time based on a range of payroll taxes, from 1.4 percent to 1.6 percent. All calculations are in constant 2010 euros, based on the GDP deflator. Calculations utilize a 2 percent discount rate.

Sources: AMECO; Eurostat; and the IMF's World Economic Outlook. See the Appendix for details.

Figure 3 Baseline, with variations in the payroll tax: stock of fund (1999-2020) 


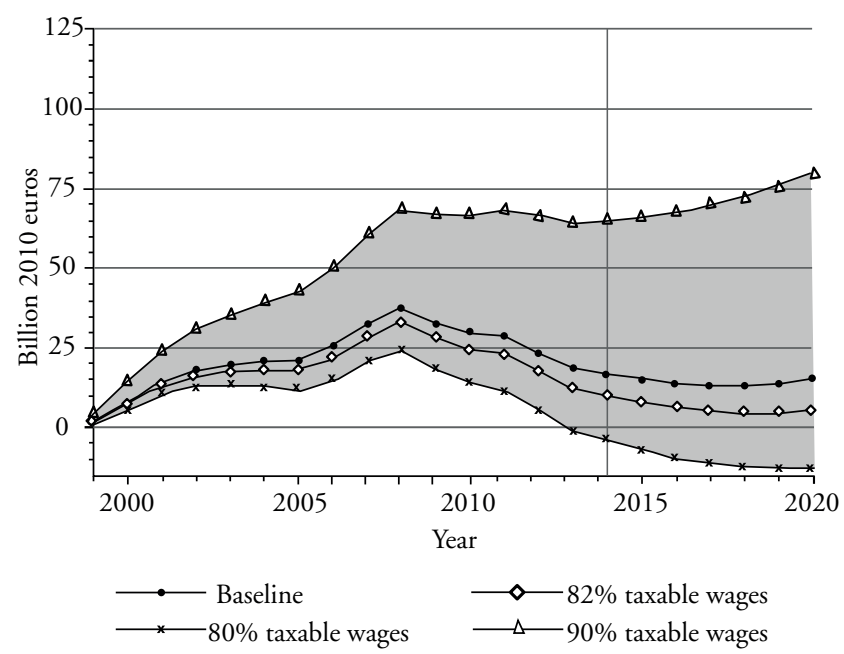

Notes: The calculations are based on a 1.5 percent payroll tax, eligibility to 100 percent of the shortterm unemployed, and benefits equal to 45 percent minimum wage replacement. The figure presents the stock of the fund over time based on values for the taxable wage base ranging from 80 to 90 percent. All calculations are in constant 2010 euros, based on the GDP deflator. Calculations utilize a 2 percent discount rate.

Sources: AMECO; Eurostat; and the IMF's World Economic Outlook. See the Appendix for details.

Figure 4 Baseline, with variations in the taxable wage base: stock of fund (1999-2020)

for 50 percent minimum wage replacement. ${ }^{14}$ In fact, with a 1.7 percent payroll tax, 50 percent minimum wage replacement is possible for all values of the taxable wage base between 80 percent and 90 percent. Furthermore, with a payroll tax of 1.6 percent, 50 percent minimum wage replacement is feasible for values of the taxable wage base greater than 84 percent. ${ }^{15}$

Finally, Figure 5 turns to variations in eligibility requirements. While the baseline calculations indicate that providing EMU-level benefits to 100 percent of the short-term unemployed is fiscally feasible, more restrictive eligibility requirements may be more politically feasible. Eligibility defined by the first 6 months of unemployment, for example, is consistent with existing UI programs in some EMU economies, including Malta, Cyprus, and Slovakia. ${ }^{16}$ On average, 70.1 percent of short-term unemployment in the sample lasts

14. An increase in the size of the fund can either be generated via increases in the taxable wage base, or in the payroll tax, and the chosen combination of these parameters influences the distributional consequences of the policy. In particular, funding the system via a relatively higher cap on income subject to payroll tax (higher taxable wage base) and a relatively lower payroll tax increases the progressivity of the tax system financing the scheme.

15. With a 1.5 percent payroll tax, on the other hand, 50 percent minimum wage replacement is not possible for any values of the taxable wage base less than or equal to 90 percent.

16. There are also stricter eligibility requirements, for example, in the Netherlands, which provides individuals with benefits on the basis of prior job tenure. Unfortunately, these types of eligibility requirements cannot be captured in the aggregate data. 


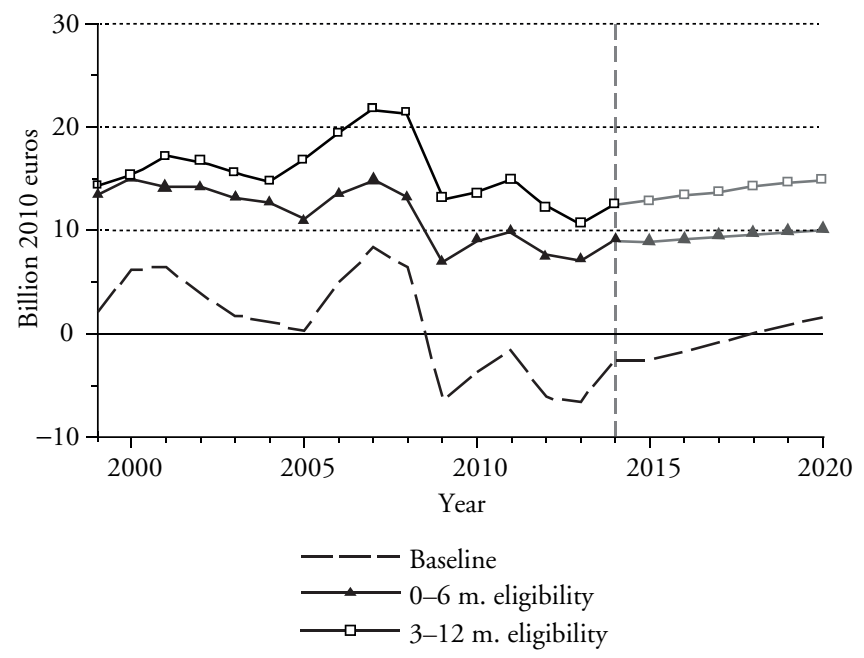

Notes: The calculations are based on a 1.5 percent payroll tax, 83 percent taxable wage base, and benefits equal to 45 percent minimum wage replacement. The figure presents the yearly surplus/deficit of the fund over time for various eligibility scenarios. All calculations are in constant 2010 euros, based on the GDP deflator. Calculations utilize a 2 percent discount rate.

Sources: AMECO; Eurostat; and the IMF's World Economic Outlook. See the Appendix for details.

Figure 5 Baseline scenario, with variations in eligibility requirements: yearly surplus or deficit (1999-2020)

0 to 6 months; thus, guaranteeing EMU-level benefits for 6 - rather than 12 - months substantially increases the accumulated stock of the fund.

Figure 5 compares the baseline (in which 100 percent of the short-term unemployed are eligible for benefits) to scenarios in which: (i) individuals are eligible for 6 months of benefits; and (ii) individuals are eligible for 9 months of benefits, beginning after 3 months of unemployment (that is, a period of unemployment is required before kick-in). Because the accumulated stock of the fund with these stricter eligibility requirements is dramatically higher than the baseline, Figure 5 plots the yearly surplus/deficit for each eligibility scenario, rather than the accumulated stock of the fund. The accumulated stock of the fund increases dramatically, however, for both variations in eligibility requirements. In 2014, for example, the accumulated fund for the baseline scenario is $€ 16.6$ billion; on the other hand, the fund holds $€ 184.5$ billion when eligibility is restricted to the first 6 months of unemployment, and $€ 250.3$ billion when benefits are provided for months 3-12 of unemployment.

Figure 5 highlights that, for each stricter definition of eligibility, the fund runs a surplus in all years, including the post-2009 crisis years. Thus, stricter eligibility requirements are strongly compatible with higher benefit levels, or lower funding taxes. Holding the payroll tax and taxable wage base equal to their baseline values ( 1.5 percent and 83 percent, respectively), 6 months of eligibility is compatible with a maximum of 65 percent minimum wage replacement, and eligibility from months 3-12 of unemployment is feasible for up to 74 percent minimum wage replacement. These replacement levels exceed current UI benefits in some countries; more importantly, however, these sensitivity calculations highlight that stricter eligibility requirements are fiscally feasible with significantly higher minimum wage replacement levels. 
Conversely, stricter eligibility requirements are also compatible with a lower funding tax. When holding the taxable wage base and minimum wage replacement levels equal to the baseline ( 83 percent and 45 percent, respectively), and providing 6 months of unemployment benefits, the fund is feasible for payroll taxes greater than or equal to 1.03 percent; for eligibility from 3-12 months of unemployment, the fund is feasible for payroll taxes greater than 0.91 percent. Thus, not only is the system feasible for the baseline institutional design, but a range of policy parameters exist whereby trade-offs can be made between, for example, benefit levels and payroll taxes while establishing an EMU-level UI system that is fiscally feasible.

\subsection{Automatic trigger for extended benefits}

One natural extension to the baseline design is an automatic trigger that partially allocates the fund's accumulated surplus towards extended-duration benefits during particularly severe crises. Extended benefits both provide additional income support and further support aggregate demand during particularly deep recessions. Automatic triggers replicate a feature of the US system, which provides benefit extensions during deep recessions both via automatic triggers and via congressional ability to legislate emergency benefits on a discretionary basis. In practice, UI extensions in the US are primarily executed through legislation rather than through the automatic trigger. In the EMU case, however, the European Commission's minimal budgetary capacity suggests it is preferable to provide extended benefits via automatic trigger.

We propose a trigger that goes into effect in response to a large increase in one member's unemployment rate, such that the trigger extends emergency benefits in response to severe asymmetric shocks. We analyse two triggers, both of which extend unemployment benefits to 18 - from 12 - months. The first trigger ('Trigger 1') goes into effect when a country's unemployment rate: (i) is more than two standard deviations greater than its mean unemployment rate for all EMU years, and (ii) exceeds 10 percent. These two conditions are fulfilled for 11 of 337 country-year pairs. The second trigger ('Trigger 2') goes into effect when a country's unemployment rate: (i) is more than 1.5 times its mean unemployment rate, and (ii) exceeds 10 percent. Trigger 2 is more expansive, going into effect for 7.1 percent of observations ( 24 of 337 country-year pairs). Note that both triggers link an individual country's trigger unemployment rate to its labor market structure, such that countries with historically higher unemployment must hit relatively higher unemployment rates to be eligible for the trigger.

Figure 6 plots the baseline fund with the automatic triggers. Both triggers first go into effect in 2005, at which time the dashed lines indicating the fund with triggers separate from the solid line indicating the baseline scenario. Subsequently, Trigger 2 further diverges from the baseline in 2011, such that Trigger 2, which provides extended benefits for more observations, depletes the accumulated stock of the fund to a greater extent than Trigger 1 . Nonetheless, the system remains fiscally feasible with both triggers. Thus, the scheme can finance extended benefits in deep recessions without increasing the payroll tax or decreasing benefit levels. Furthermore, both triggers execute primarily after 2008, so are successful in responding to the severity of crisis in post-2008 Europe.

Finally, note that the precise country-year pairs for which the triggers go into effect vary with the trigger's design. Both first execute in Germany in 2005. Trigger 1 (the stricter rule) again goes into effect in Portugal in 2012 and 2013; in Slovenia in 2013; in Greece from 2012 to 2015; and in Cyprus from 2013 to 2018. After going into effect in Germany in 2005, Trigger 2 finances extended benefits in Cyprus from 2012 to 2020; Portugal from 2011 to 2016; and Greece from 2011 to 2018. Thus, both the number of country-year pairs for which each trigger is in effect and the 'winners' and 'losers' of 


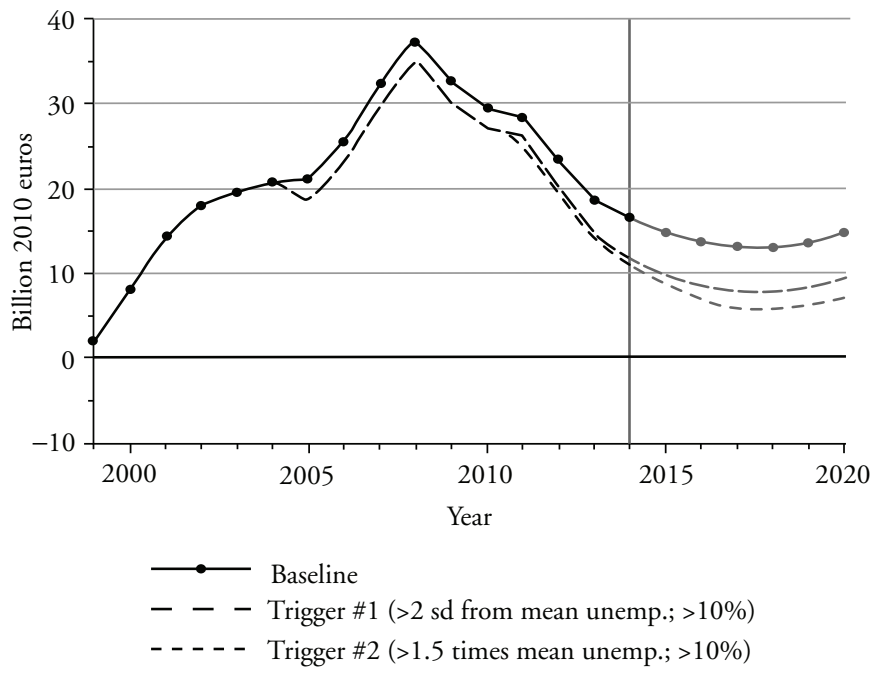

Notes: The baseline calculations are based on a 1.5 percent payroll tax, 83 percent taxable wage base, and benefits equal to 45 percent minimum wage replacement provided to 100 percent of the short-term unemployed. The figure includes two automatic triggers that provide extended-duration unemployment benefits through 18 months. Trigger 1 goes into effect when a country's unemployment rate is more than two standard deviations greater than its mean unemployment rate and exceeds 10 percent. Trigger 2 goes into effect when a country's unemployment rate is more than 1.5 times its mean unemployment rate and exceeds 10 percent. Both triggers first go into effect in 2005, at which time the dotted lines separate from the baseline scenario. Trigger 2 executes again in 2011. All calculations are in constant 2010 euros, based on the GDP deflator. Calculations utilize a 2 percent discount rate.

Sources: AMECO; Eurostat; and the IMF's World Economic Outlook. See the Appendix for details.

Figure 6 Automatic trigger for extended benefits: stock of fund (1999-2020)

the particular policy design vary, such that the trigger's design entails within-eurozone distributional trade-offs. Importantly, however, the fact that the trigger first goes into effect for Germany indicates that the provision of extended benefits need not be limited to 'peripheral' EMU countries.

\section{POLITICAL ECONOMY IMPLICATIONS: DISTRIBUTION AND OUTPUT STABILIZATION}

\subsection{Distributional implications}

One important question with regard to the political feasibility of the system concerns distributional outcomes across eurozone countries. As discussed above, the proposed institutional design of the scheme, which links contributions and benefit levels to each country's wage base, mitigates some distributional impacts by construction. Nonetheless, growing evidence of structural imbalances suggests that, in the absence of strict country-level caps linking contributions and benefits over the business cycle, some redistribution is likely.

Table 4 lays out the year-by-year distributional impacts of the baseline scheme. Each cell records the yearly ratio of a country's contributions into the scheme relative to benefits 
received from the scheme (Contributions ${ }_{i, t} /$ Benefits $_{i, t}$ ). When the ratio is greater than one, the country is a net contributor to the UI scheme; when the ratio is less than one, the country is a net beneficiary. First, from Table 4 it is useful to note that - consistent with the fact that the scheme accumulates a positive stock of funds from a starting point of zero - more country-year pairs are net contributors than net beneficiaries. Second, Table 4 indicates that countries' net contributor/beneficiary status is not necessarily consistent over time, and does not clearly follow core-periphery patterns. Not only do some countries - including Cyprus, Portugal, Ireland, and Italy - alternate between being net beneficiaries and net contributors, but there are also some surprising coreperiphery trends. France, for example, is a net beneficiary in all years except 2008; the Netherlands is a net beneficiary in 2013 and 2014; and Portugal is a net contributor until 2009.

A third, and perhaps the most important, conclusion from Table 4 is that net contributor/net beneficiary status is closely linked to each country's business cycle, such that countries' net positions increase when they are in expansions and decrease when in contractions. Of 337 observations, 91.1 percent of net contributors are country-years with positive GDP growth. This relationship is captured in Table 4 by the bold italicized cells, which indicate observations for which a country had negative growth. The column indicating 2009, when all EMU countries contracted, is particularly informative: even when countries with negative growth remain net contributors, this net position declines relative to the last year with positive growth. ${ }^{17}$ Again, this feature of the system is largely by construction: because UI is an automatic stabilizer, countries automatically pay more in contributions when the economy is booming (the wage base is high and unemployment is low) relative to recessions (as the wage base shrinks and unemployment rises). This distributional analysis, consequently, suggests that the extension of fiscal transfers via automatic stabilizers is a particularly useful starting point for designing fiscal transfers in the eurozone: by clearly linking a country's change in net contributions to its business cycle, automatic stabilizers limit sustained distributional consequences.

However, despite variations in some countries' net contributor/net beneficiary status over time mentioned above, Table 4 does suggest some sustained distributional impacts. Perhaps most important, given the current political economy of Europe, is that - in the baseline scenario - Greece is a net beneficiary in all years and, despite 'breaking even' in 2005, Germany is a net contributor in all other years. When interpreting this result, at least two points are relevant to note. First, whereas prior to 2009 Greece's net position was approaching one, Greece's net beneficiary status increased after the onset of the crisis. Second, while Germany is always a net contributor in the baseline scheme, the automatic triggers in Section 4.3 provide extended benefits to Germany in 2005, such that Germany is a net beneficiary in 2005 .

Nonetheless, Table 4 raises the question of the extent to which this system generates permanent redistributive transfers across eurozone countries. This relationship between fiscal transfer mechanisms and permanent fiscal transfers is an important theme in the academic literature and policy-based discussions on the eurozone and EMU-wide UI (Dullien 2013; Claeys et al. 2014). To explore the magnitude of permanent transfers generated by the baseline institutional design, Table 5 records accumulated net benefits/ contributions received/incurred by each eurozone country, relative to that country's GDP. Each column shows aggregated net benefits/contributions for all years between each country's introduction to the euro and 2020 (including projections), 2014 (the

17. The only exception is Finland, for which net beneficiary status in 2012 remains constant from 2011, despite positive growth in 2011 and a contraction in 2012. 


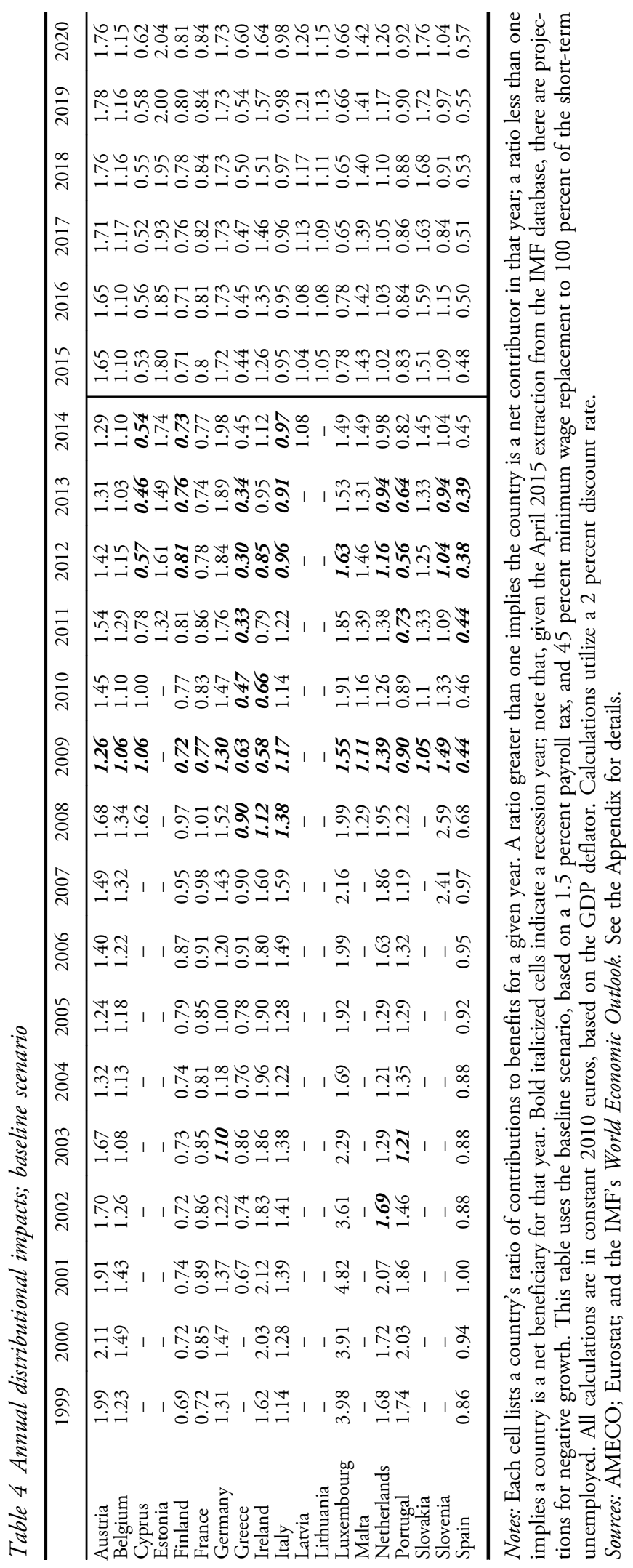


Table 5 Aggregated net contributions as a percentage of GDP; baseline scenario

\begin{tabular}{lccc}
\hline & Through 2007 & Through 2014 & Through 2020 \\
\hline Austria & $0.18 \%$ & $0.16 \%$ & $0.18 \%$ \\
Belgium & $0.09 \%$ & $0.07 \%$ & $0.07 \%$ \\
Cyprus & - & $-0.16 \%$ & $-0.22 \%$ \\
Estonia & - & $0.16 \%$ & $0.20 \%$ \\
Finland & $-0.14 \%$ & $-0.14 \%$ & $-0.14 \%$ \\
France & $-0.08 \%$ & $-0.09 \%$ & $-0.10 \%$ \\
Germany & $0.10 \%$ & $0.15 \%$ & $0.17 \%$ \\
Greece & $-0.08 \%$ & $-0.24 \%$ & $-0.26 \%$ \\
Ireland & $0.20 \%$ & $0.06 \%$ & $0.09 \%$ \\
Italy & $0.09 \%$ & $0.06 \%$ & $0.04 \%$ \\
Latvia & - & $0.04 \%$ & $0.06 \%$ \\
Lithuania & - & - & $0.04 \%$ \\
Luxembourg & $0.25 \%$ & $0.21 \%$ & $0.09 \%$ \\
Malta & - & $0.10 \%$ & $0.11 \%$ \\
Netherlands & $0.17 \%$ & $0.13 \%$ & $0.11 \%$ \\
Portugal & $0.15 \%$ & $0.03 \%$ & $0.00 \%$ \\
Slovakia & - & $0.07 \%$ & $0.12 \%$ \\
Slovenia & $0.45 \%{ }^{*}$ & $0.19 \%$ & $0.11 \%$ \\
Spain & $-0.04 \%$ & $-0.29 \%$ & $-0.33 \%$ \\
\hline
\end{tabular}

Notes: Each cell lists a country's net contributions (total contributions less benefits received) aggregated over all years between the country's introduction to the euro and the year listed in the column heading, and measured relative to the country's GDP. This table uses the baseline scenario, based on a 1.5 percent payroll tax, and 45 percent minimum wage replacement to 100 percent of the shortterm unemployed. All calculations are in constant 2010 euros, based on the GDP deflator.

*Note that this observation is based on only 1 year of data, because Slovenia entered the EMU in 2007.

Sources: AMECO; Eurostat; and the IMF's World Economic Outlook. See the Appendix for details.

last year for which observed data is available), and 2007 (for a pre-crisis comparison), respectively. These accumulated surpluses/deficits are measured relative to GDP to explore the economic magnitude of net contributor/net beneficiary status over time.

Table 5 highlights that, while some countries do accumulate net contributor/net beneficiary positions, these net positions are quite small as a percentage of GDP. For example, for the full sample period and including projections through 2020, Germany's accumulated contributions to the fund constitute 0.17 percent of GDP. In part, this result reflects that UI is a small percentage of GDP. Nonetheless, Table 5 indicates that the aggregation of net contributions/net benefits over time does not magnify annual flows so as to generate larger-scale permanent redistributions. Finally, Table 5 points to the specificity of the post-crisis period, wherein crisis countries' net beneficiary status increases over the sample period, and vice versa.

\subsection{Stabilization properties}

The logic for fiscal transfers in a monetary union is based on the role of expansionary fiscal policy in supporting aggregate demand - and, in turn, output - following adverse macroeconomic shocks. A growing empirical consensus points to a positive multiplier effect of expansionary fiscal policy (Blanchard/Leigh 2013; Batini et al. 2014). 
Furthermore, traditional Keynesian theory, as well as more recent empirical evidence (Auerbach/Gorodnichenko 2012; Fazzari et al. 2015), emphasizes the point-in-business-cycle dependence of fiscal multipliers. Thus, the same country's multiplier is larger during a recession than when at, or approaching, a business cycle peak. Lack of business cycle synchronization in the EMU, consequently, implies that the stabilizing potential of fiscal spending is amplified when EMU-level spending is directed towards countries furthest from their business cycle peaks, pointing to a role for fiscal transfers via automatic stabilizers in the EMU.

In this section, we lay out simple stylized calculations that point to a positive output stabilization potential of the baseline system. Note, however, that there is an inverse relationship between the magnitude of fiscal transfers and the potential for output stabilization. Thus, relative to the baseline, a system that includes automatic triggers or provides higher minimum wage replacement generates a larger fiscal 'shock' and has greater stabilization potential. Recall, furthermore, that UI is a small percentage of total government expenditure; as such, we do not expect a large stabilization effect from this policy in isolation. Nonetheless, a small but positive stabilization effect points to a role for 'federalized' UI as one useful tool in the design of a more stable EMU architecture. ${ }^{18}$

The stabilization potential of the UI scheme can be analysed both for individual countries, and at the eurozone level. In both cases, we first isolate the fiscal transfer for each country-year pair - defined as the country- and year-specific surplus or deficit - normalized by GDP. This fiscal 'shock' captures the yearly spending transfer into or out of a country. In the baseline scheme, these fiscal transfers as a percentage of individual countries' GDP are small, exceeding 0.5 percent of a country's GDP only for Spain between 2009 and 2015 (the highest value being 0.77 percent in 2012) and Greece from 2011 to 2013 (0.74 percent in 2012). Importantly, during these periods unemployment in both Greece and Spain exceeds 17.9 percent, signifying significant 'slack' in the countries receiving transfers.

We apply the fiscal transfer for each country-year (starting with each country's first year of EMU membership) to empirical estimates for fiscal spending multipliers in order to adjust each country's observed GDP by the effect of its participation in the fiscal transfer scheme. Following the recent empirical literature on multipliers, we differentiate the magnitude of fiscal multipliers in expansions and contractions, and apply multipliers ranging from 0 to 1 for expansions, and 1 to 2.5 for contractions (Batini et al. 2014). We then derive subsequent years' GDP figures using ex-ante GDP growth rates and repeating the GDP adjustment procedure, based on the following year's transfer and the relevant multiplier. These calculations point to the potential for output stabilization in countries facing deep recessions: in the presence of the baseline scheme, Spanish GDP would contract by $0.3-1.4$ percent in 2012, compared to an observed 2.1 percent contraction. Similarly, compared to a 6.6 percent decline in Greek GDP in 2012, GDP would decline by 4.9-5.9 percent. Thus, we expect a clear positive stabilization effect for individual countries during deep recessions.

We can, similarly, analyse the magnitude of the stabilization effect at the eurozone level by aggregating the adjusted GDP series described above to the EMU level. In 2009, for

18. The stimulus effect relies on an underlying assumption that any reduction in a country's deficit due to the UI scheme allows national governments to increase their spending accordingly, by an equal amount. In other words, if countries chose to run smaller fiscal deficits, rather than redirect discretionary fiscal policy to other purposes, the stabilization effect would be 'small or non-existent ... [although a] benefit in this case might arise from the reduced public debt level and the consequent positive confidence effect' (Claeys et al. 2014: 4). 
example, eurozone GDP contracted 3.77 percent. Applying the EMU-wide UI program, however, suggests that EMU-level GDP would have contracted 3.61-3.71 percent. Thus, at the eurozone level, the magnitude of the stabilization effect is small but positive. These figures suggest that an EMU-wide UI program can mitigate the depth of EMU-level downturns and, as such, point to a role for fiscal transfers in mitigating asymmetric shocks to EMU countries. Furthermore, these results indicate the usefulness of fiscal transfers extended via automatic stabilizers, which both support countries furthest from their business cycle peaks and act as a break on growth for countries reaching full employment levels of output.

\section{CONCLUSION}

The post-2009 period in the eurozone has raised questions about the sustainability of the EMU's current structure, and pointed to a need for policy-oriented discussions exploring institutions with the potential to contribute to a more stable eurozone design. This paper contributes to this discussion by detailing an institutional design and cost calculations for an EMU-level UI system. The baseline system provides benefits to the short-term unemployed by extending existing national systems of revenue collection and disbursement to a fund operated at the EMU level. Cost calculations indicate that such a system is one fiscally feasible policy mechanism that can support both household incomes and aggregate demand following asymmetric shocks to EMU countries. Furthermore, sensitivity analysis indicates that, while the selection of institutional parameters does vary the accumulated surplus within the fund, the system is feasible for a range of policy designs.

It is important to note that the scheme discussed in this paper is neither proposed as a singular solution to structural problems plaguing the eurozone, nor a magic bullet to end the current eurozone 'debt' crisis. In particular, this scheme helps mitigate asymmetric shocks to eurozone countries, rather than differences in labor market characteristics across EMU countries; for this reason the system emphasizes short-term unemployment. Predicted stabilization effects, furthermore, highlight that this system alone cannot eliminate the impact of asymmetric shocks to EMU economies. Nonetheless, we highlight the potential for positive output stabilization effects. Thus, the analysis suggests that an EMU-wide UI scheme is one policy that can contribute to a broader agenda targeting weaknesses in EMU design and, more specifically, to a wider system of fiscal transfers.

One clear advantage of the emphasis on short-term unemployment is that distributional implications across eurozone countries are limited, increasing the program's political feasibility. Specifically, distributional implications clearly vary with individual countries' business cycles, such that there is a clear barometer defining increases and decreases in net contributions. These characteristics of the system are largely by design: each country's contributions into the system and benefits received from the system are linked to its business cycle, because UI is an automatic stabilizer, and also to its own wage levels. Importantly, the selection of institutional parameters also carries distributional consequences within eurozone countries, which are only alluded to in this paper, but which are an additional feature of the political economy of any changes to the EMU architecture.

Finally, the results presented in this paper point to the usefulness of fiscal transfers extended via automatic stabilizers. Automatic stabilizers, by construction, link each country's net contributions to a system of fiscal transfers to their place in the business cycle. As such, they inherently aim to mitigate the impacts of asymmetric shocks that generate divergence among member countries. Output fluctuations are dampened both for countries in contractions and in booms: countries facing recession receive positive net transfers 
that support aggregate demand, whereas contributions to the fund increase as countries near their business cycle peak. The post-2009 period in Europe, furthermore, highlights that asymmetric shocks may be highly persistent in monetary unions, such as the EMU, given the lack of policy tools individual member states have to combat such shocks. Thus, by mitigating the effects of asymmetric shocks, this policy can contribute to a larger set of EMU-level fiscal transfers, and a more stable EMU architecture.

\section{REFERENCES}

Alatvilla, C. (2004): Do EMU members share the same business cycle?, in: Journal of Common Market Studies, 42(5), 869-896.

Alvaredo, F., Atkinson, A., Piketty, T., Saez, E., Zucman, G. (2014): The World Top Incomes Database, URL: http://www.wid.world/.

AMECO Database, Annual macro-economic database of the European Commission's Directorate General for Economic and Financial Affairs, URL: http://ec.europa.eu/economy_finance/db_indicators/ameco/zipped_en.htm.

Andor, L. (2014): Social dimension of the Economic and Monetary Union: what lessons to draw from the European elections? European Commission Press Release Database, URL: http:// europa.eu/rapid/press-release_SPEECH-14-455_en.htm.

Auerbach, A., Gorodnichenko, Y. (2012): Measuring the output responses to fiscal policy, in: American Economic Journal: Economic Policy, 42(2), 1-27.

Auerbach, A., Gorodnichenko, Y. (2013): Output spillovers from fiscal policy, in: American Economic Review, 103(3), 141-146.

Baldwin, R. (2006): The Euros trade effects, European Central Bank Working Paper Series No 594, March.

Batini, N., Eyraud, L., Forni, L., Weber, A. (2014): Fiscal multipliers: size, determinants and use in macroeconomic projections, International Monetary Fund: Fiscal Affairs Department, Technical Notes and Manuals, September.

Beblavý, M., Marconi, G., Maselli, I. (2015): A European unemployment benefits scheme: the rationale and the challenges ahead, Centre for European Policy Studies Report No 119.

Blanchard, O., Leigh, D. (2013): Growth forecast errors and fiscal multipliers, NBER Working Paper No 18779.

Claeys, G., Darvas, Z., Wolff, G. (2014): Benefits and drawbacks of European unemployment insurance, Bruegel Policy Brief Issue 2014/06.

Commission of the European Communities (1975): Report of the study group Economic and Monetary Union 1980 [Marjolin Report], Brussels: Directorate-General of Economics and Financial Affairs.

Crespo-Cuaresma, J., Fernandez-Amador, O. (2013): Business cycle convergence in the EMU: a first look at the second moment, in: Journal of Macroeconomics, 37, 265-284.

De Grauwe, P. (2006): What have we learned about monetary integration since the Maastricht Treaty?, in: Journal of Common Market Studies, 44(4), 711-730.

De Grauwe, P. (2012): Governance of a fragile Eurozone, in: Australian Economic Review, 45(3), 255-268.

De Grauwe, P. (2013): Design failures in the Eurozone: can they be fixed?, LSE Europe in Question Discussion Paper Series, No 57/2013.

Dolls, M., Fuest, C., Neumann, D., Peichl, A. (2014): An unemployment insurance scheme for the euro area: evidence at the micro level, May, URL: http://euro-frame.org/files/user_upload/euroframe/docs/2014/Session\%205/EUROF14_Dolls_etal.pdf.

Dullien, S. (2007): Improving economic stability in Europe: what the euro area can learn from the United States unemployment insurance, Stiftung Wissenschaft \& Politik Working Paper 1.

Dullien, S. (2012): A European unemployment insurance as a stabilization device - selected issues, Paper prepared for the European Commission (DG EMPL), URL: ec.europa.eu/social/Blob Servlet?docId $=10437 \&$ langId $=$ en . 
Dullien, S. (2013): A euro-area wide unemployment insurance as an automatic stabilizer: why benefits and who pays?, Paper prepared for the European Commission (DG EMPL), URL: http://ec. europa.eu/social/BlobServlet?docId=12510\&langId=en.

Dullien, S., Fichtner, F. (2013): A common unemployment insurance system for the euro area, DIW Economic Bulletin.

Dullien, S., Fritsche, U. (2009): How bad is divergence in the euro zone? Lessons from the United States and Germany, in: Journal of Post Keynesian Economics, 31(3), 431-457.

Dullien, S., Schwarzer, D. (2009): Bringing macroeconomics into the EU budget debate: why and how?, in: Journal of Common Market Studies, 47(1), 153-174.

Eurostat Database, European Commission, URL: http://ec.europa.eu/eurostat/data/database.

Fazzari, S., Morley, J., Panovska, I. (2015): State-dependent effects of fiscal policy, in: Studies in Nonlinear Dynamics and Econometrics, 19(3), 285-313.

Hein, E., Detzer, D. (2014): Coping with imbalances in the euro area: policy alternatives addressing divergences and disparities between member countries, Levy Working Paper, No 816.

IMF (International Monetary Fund), World Economic Outlook Database, URL: http://www.imf.org/ external/ns/cs.aspx?id=28.

IMF (International Monetary Fund) (2015): Greece: an update of the IMF staffs preliminary public debt sustainability analysis, IMF Country Report No 15/186, 14 July, URL: https://www.imf. org/external/pubs/ft/scr/2015/cr15186.pdf.

Jara, H., Sutherland, H. (2014): The implications of an EMU unemployment scheme for supporting incomes, EURMOD Working Paper No EM 5/14.

Kenen, P. (1969): The theory of optimum currency areas: an eclectic view, in: Mundell, R., Swoboda, A. (eds), Monetary Problems of the International Economy, Chicago and London: University of Chicago Press, 41-60.

Krugman, P. (2012): Revenge of the optimum currency area, in: NBER Macroeconomics Annual, 27(1), 439-448.

Mundell, R. (1961): A theory of optimum currency areas, in: American Economic Review, 51(4), 657-665.

Nikiforos, M., Carvalho, L., Schroder, C. (2015): Twin deficits in Greece: in search of causality, in: Journal of Post Keynesian Economics, 38(2), 302-330.

Obstfeld, M. (2013): Finance at center stage: some lessons of the euro crisis, European Commission, European Economy Economics Papers No 493.

Oh, H., Reis, R. (2012): Targeted transfers and the fiscal response to the Great Recession, in: Journal of Monetary Economics, 59(S), S50-S64.

SSA (2013): Annual statistical supplement to the social security bulletin, Social Security Administration publication No 13-11700, February, Washington, DC.

SSA (2014): Social security programs throughout the world: Europe 2014, Social Security Administration publication No 13-11801, September, Washington, DC.

Varoufakis, Y. (2011): The Global Minotaur: American, the True Origins of the Financial Crisis and the Future of the World Economy, London: Zed Books. 


\section{APPENDIX CONSTRUCTION OF DATASET}

The calculations in this paper utilize data from AMECO, Eurostat, and the IMF's World Economic Outlook. Data for gross wages, total compensation of employees, the number of unemployed, and GDP deflators are from AMECO for 1999-2014. AMECO includes gross wage data for all EMU countries except Malta; for Malta we utilize total compensation to calculate gross wages by assuming that the ratio of wages to compensation is equal to the EMU median. AMECO also includes gross wage projections through 2016.

We augment the AMECO data with minimum wage and unemployment duration data from Eurostat from 1999-2014, and minimum wage data for 2015. The minimum wage is a biannual average of minimum wage statistics published 1 January and 1 July; for 2015 we use the 1 January minimum wage. As noted in footnote 9, Austria, Cyprus, Finland, Germany, and Italy do not have a minimum wage for some or all of the years in our sample. For these countries we construct a shadow minimum wage utilizing the average yearly relationship between average and minimum wages in other EMU countries (approximately 50 percent).

Finally, we use projections for GDP growth, the GDP deflator, the unemployment rate, and total population from the IMF's World Economic Outlook through 2020. While AMECO provides gross wage projections for 2015 and 2016, projections for gross wages from 2017 to 2020 as well as unemployment duration (short-term unemployment) are unavailable. We calculate gross wage projections by assuming that the ratio of gross wages to GDP is constant for 2017-2020, equal to the average of the last years for which there are data. This assumption utilizes that the ratio of gross wages to GDP is fairly constant over time in each eurozone country over the relevant time period, consistent with a common stylized assumption that the wage share is constant, at least over short time periods.

Second, IMF projections include the unemployment rate, but not the duration of unemployment, or the numbers of unemployed or employed workers. To calculate the number of short-term unemployed, we first impute the size of the labor force and the numbers of unemployed and employed workers using population projections, by assuming the labor force is a constant share of population. We then assume a constant share of short-term unemployment in total unemployment to calculate the number of long-term and short-term unemployed. Across the sample, a one-unit increase in the unemployment rate is associated with a 1.5 unit increase in the share of long-term unemployment in total unemployment. Note that this assumption implies the short-term and long-term unemployed are reincorporated into employment at the same rate during recoveries. Because short-term unemployment generally falls more quickly than long-term unemployment during recoveries, this assumption is relatively stringent and biases the projection calculations against fiscal feasibility. Finally, we apply the same methodology to generate projections for various unemployment durations (Figures 5 and 6). 